\title{
Zinc borate chemical garden and zinc borate powders from tincal mineral and zinc sulfate heptahydrate
}

\author{
Burcu Alp1 ${ }^{1}$ Mehmet Gönen², Sevdiye Atakul Savrik², Devrim Balkose ${ }^{4^{*}}$ \\ 'Süleyman Demirel University, Department of Chemical Engineering, Isparta, 32260, Turkey, \\ ORCID orcid.org/0000-0002-0380-2020 \\ ${ }^{2}$ Süleyman Demirel University, Department of Chemical Engineering, Isparta, 32260, Turkey, \\ ORCID orcid.org/0000-0001-5780-4622 \\ ${ }^{3}$ Akzo Nobel, Izmir, 35410 Turkey, ORCID orcid.org/0000-0002-1402-0569 \\ ${ }^{4}$ Izmir Institute of Technology, Department of Chemical Engineering, Izmir, 35430, Turkey, \\ ORCID orcid.org/0000-0002-1117-9486
}

\section{ARTICLE INFO}

Article history:

Received October 12, 2020

Accepted January 2, 2021

Available online March 31, 2021

Research Article

DOI: $10.30728 /$ boron.809041

Keywords:

Chemical garden

Osmotic pressure

Tincal

Zinc borate

Zinc sulfate

\begin{abstract}
The formation of the first membrane, the swelling of the crystal by incoming water from the semipermeable membrane and the formation of irregular shaped branches were observed by optical microscopy, when zinc sulfate heptahydrate crystals were immersed in saturated borax solution. The powders obtained by mixing dilute aqueous borax and zinc sulfate solutions had $\mathrm{B}, \mathrm{O}, \mathrm{Na}, \mathrm{S}$ and $\mathrm{Zn}$ elements. Presence of $\mathrm{Na} \mathrm{Zn}_{1 / 2} \mathrm{~B}_{4} \mathrm{O}_{7} \cdot \mathrm{xH}_{2} \mathrm{O}$ was indicated by EDX analysis. The molar ratio of $\mathrm{B}_{2} \mathrm{O}_{3} / \mathrm{ZnO}$ in powders was around 2 . FTIR analysis indicated the ratio of absorbance values of asymmetric stretching vibrations of $\mathrm{B}_{33}-\mathrm{O}$ at 1351 $\mathrm{cm}^{-1}$ to that of $\mathrm{B}_{(4)}-\mathrm{O}$ at $1026 \mathrm{~cm}^{-1}$ increased with their heating time at $90^{\circ} \mathrm{C}$ during their preparation. X-ray diffraction patterns indicated the presence of $\mathrm{Zn}(\mathrm{OH})_{2}$ and $\mathrm{Zn}_{4}(\mathrm{OH})_{6}\left(\mathrm{SO}_{4}\right) \cdot 4 \mathrm{H}_{2} \mathrm{O}$. The zinc borate compounds in the powders were not crystalline since no sharp peaks related to zinc borates were present in $\mathrm{X}$-ray diffraction diagram. There were two mass loss steps in TG curves of the powders. The first step at $150-350^{\circ} \mathrm{C}$ and the second step at $700-950^{\circ} \mathrm{C}$ were due to elimination of water and due to decomposition of sulfate ions respectively. The submicron powders were a mixture of zinc borate, $\mathrm{Zn}(\mathrm{OH})_{2}, \mathrm{Zn}_{4}(\mathrm{OH})_{6}\left(\mathrm{SO}_{4}\right) \cdot 4 \mathrm{H}_{2} \mathrm{O}$ and $\mathrm{Na} \mathrm{Zn}_{1 / 2} \mathrm{~B}_{4} \mathrm{O}_{7} \cdot \mathrm{xH}_{2} \mathrm{O}$ and they could be used as lubricant additive due to their small particle size of $600 \mathrm{~nm}$.
\end{abstract}

\section{Introduction}

Chemical gardens are the hollow fibers formed by immersion of a soluble metal-salt particle in an aqueous solution containing either of the silicate, phosphate, carbonate, oxalate, sulfide or hydroxide ions. The possible reactants in chemical gardens and their mechanism of formation are summarized by Barge et al. [1]. The gelatinous precipitate formed around the salt particle acts as a membrane and allows the passage of small water molecules and does not allow the passage of large metal ions [1]. Membrane bursts when the osmotic pressure inside becomes higher than its tensile strength. The metal-ion solution from crystal side ejects into outer solution and tubular precipitates form around the flow creating hollow chemical garden tubes [2]. Crystals of cations of group II [2] and the transition metals [3-7] were used as salts added to silicate solution. The kinetics of formation of silica garden tubes prepared using different metal salts were investigated by Glaab et al. [8]. Other solutions other than silicates were also used in chemical gardens. Hexacyanoferrate $\mathrm{Fe}(\mathrm{CN})_{6}^{-1}[9,10], \mathrm{OH}^{-}[11]$ anions are examples for this case. Real time X-ray fluorescence (XRF) movie technique was used to monitor chemical garden fiber formation [12].

Zinc borates are commercially important chemicals [13]. They can be obtained either by reaction of $\mathrm{ZnO}$ and $\mathrm{H}_{3} \mathrm{BO}_{3}[14]$ or reaction of borax with zinc salts [1523].

The reactions of borate anion with zinc cation are shown below:

$$
\begin{gathered}
\mathrm{B}_{4} \mathrm{O}_{5}(\mathrm{OH})_{4}{ }^{2-}(\mathrm{aq})+\mathrm{Zn}^{2+}(\mathrm{aq})+\mathrm{H}_{2} \mathrm{O}(\mathrm{l}) \rightarrow \\
\mathrm{Zn}\left[\mathrm{B}_{4} \mathrm{O}_{5}(\mathrm{OH})_{4}\right\rceil \cdot \mathrm{H}_{2} \mathrm{O}(\mathrm{s}) \\
\mathrm{Zn}\left[\mathrm{B}_{4} \mathrm{O}_{5}(\mathrm{OH})_{4}\right] \cdot \mathrm{H}_{2} \mathrm{O}(\mathrm{s})+2 \mathrm{H}_{2} \mathrm{O}(\mathrm{l}) \rightarrow \\
\mathrm{Zn}\left\lceil\mathrm{B}_{3} \mathrm{O}_{3}(\mathrm{OH})_{5}\right\rceil \mathrm{H}_{2} \mathrm{O}(\mathrm{s})+\mathrm{B}(\mathrm{OH})_{3}(\mathrm{~s}) \\
\mathrm{Zn}\left[\mathrm{B}_{3} \mathrm{O}_{3}(\mathrm{OH})_{5}\right] \cdot \mathrm{H}_{2} \mathrm{O}(\mathrm{s}) \rightarrow \\
\mathrm{Zn}\left[\mathrm{B}_{3} \mathrm{O}_{3}(\mathrm{OH})_{5}\right](\mathrm{s})+\mathrm{H}_{2} \mathrm{O}(\mathrm{l})
\end{gathered}
$$


Kıpçak et al. [19] synthesized zinc borate using tincalconite mineral according to the following reaction in Equation 4.

$$
\begin{aligned}
& \mathrm{ZnSO}_{4} \cdot 7 \mathrm{H}_{2} \mathrm{O}+\mathrm{Na}_{2} \mathrm{~B}_{2} \mathrm{O}_{7} \cdot 5 \mathrm{H}_{2} \mathrm{O}+ \\
& 3 \mathrm{H}_{3} \mathrm{BO}_{3}+x \mathrm{H}_{2} \mathrm{O} \rightarrow \\
& 1 / 3\left[\mathrm{Zn}_{3} \mathrm{~B}_{6} \mathrm{O}_{12} \cdot 3.5 \mathrm{H}_{2} \mathrm{O}\right]+ \\
& \quad \mathrm{Na}_{2} \mathrm{SO}_{4}+5 \mathrm{H}_{3} \mathrm{BO}_{3}+\mathrm{yH}_{2} \mathrm{O}
\end{aligned}
$$

$\mathrm{Zn}\left(\mathrm{H}_{2} \mathrm{O}\right) \mathrm{B}_{2} \mathrm{O}_{4} \cdot 0.12 \mathrm{H}_{2} \mathrm{O}$ was obtained from $\mathrm{ZnSO}_{4} \cdot 7 \mathrm{H}_{2} \mathrm{O}$, $\mathrm{K}_{2} \mathrm{~B}_{4} \mathrm{O}_{7} \cdot 4 \mathrm{H}_{2} \mathrm{O}$, and $\mathrm{NH}_{4} \mathrm{HB}_{4} \mathrm{O}_{7} \cdot 3 \mathrm{H}_{2} \mathrm{O}$ in $\mathrm{H}_{2} \mathrm{O}$ with $\mathrm{pH}$ regulated to 9.5 with $3 \mathrm{~mol} \mathrm{dm}^{-3} \mathrm{NaOH}$ solution by Liang et al. [22].

$4 \mathrm{ZnO} \cdot \mathrm{B}_{2} \mathrm{O}_{3} \cdot \mathrm{H}_{2} \mathrm{O}$ having $2 \mathrm{D}$ and $3 \mathrm{D}$ nano/microstructures were obtained by hydrothermal method in the presence of surfactant polyethylene glycol-300 from $\mathrm{Na}_{2} \mathrm{~B}_{4} \mathrm{O}_{7} \cdot 10 \mathrm{H}_{2} \mathrm{O}$ and $\mathrm{ZnSO}_{4}$ [21,24]. Nano discs of $2 \mathrm{ZnO} \cdot 3 \mathrm{~B}_{2} \mathrm{O}_{3} \cdot 3 \mathrm{H}_{2} \mathrm{O}$ were obtained from aqueous borax and zinc salt solutions by the addition of oleic acid [25]. Lubricant additive zinc borate nanoparticles were obtained from borax decahydrate and zinc nitrate hexahydrate solutions by addition of sodium dodecyIbenzenesulfonate [15], PEG 4000 and Span 60 [26], phosphate ester [27] as templates.

Parallel to zinc borate formation the possibility of $\mathrm{Zn}(\mathrm{OH})_{2}$ formation according to Equation 5 was indicated by Savrik et al. [26].

$$
\mathrm{Zn}^{2+}(\mathrm{aq})+\mathrm{OH}^{-}(\mathrm{aq}) \rightarrow \mathrm{Zn}(\mathrm{OH})_{2}(\mathrm{~s})
$$

Polat and Sayan [28] investigated the change of properties of zinc borate with stirring rate, temperature and reactant feed rate. For zinc borate crystallization, sodium tetraborate decahydrate and zinc sulfate heptahydrate were used as reactants. The results showed that the obtained crystals were in the form of $\mathrm{Zn}_{2} \mathrm{~B}_{6} \mathrm{O}_{11} \cdot 7 \mathrm{H}_{2} \mathrm{O}$ and the operating conditions change the size, morphology, and filtration characteristics of the zinc borate crystals. Box-Behnken design with response surface methodology showed that the data sufficiently fit the second-order polynomial model for the variables of stirring rate, temperature, and reactant feed rate. The minimum particle size $(3.3 \mu \mathrm{m})$ was obtained at $450 \mathrm{rpm}$ stirring rate, $85^{\circ} \mathrm{C}$ temperature and $300 \mathrm{~cm}^{3} \mathrm{~h}^{-1}$ reactant feed rate.

In this study, it was aimed to obtain and monitor the formation of chemical garden fibers by immersing zinc sulfate heptahydrate crystals in borax decahydrate solution prepared from purified Kırka tincal mineral. It was also aimed to characterize purified tincal mineral and to identify products in the powders formed by the reaction of dilute borax solution with dilute zinc sulfate heptahydrate solution. Elemental analysis (EDX), Fourier transform infrared spectroscopy (FTIR), X-ray dif- fraction (XRD), thermal gravimetric (TG) analysis and scanning electron microscopy (SEM) techniques were used for this purpose.

\section{Materials and Methods}

\subsection{Materials}

Tincal mineral from Etibank Kırka Mines, anionic flocculant SP100A (American Cynamid Company) and zinc sulfate heptahydrate (99\%) from Merck were used in the experiments.

\subsection{Purification of Tincal Mineral}

Tincal mineral was purified from impurities by flocculation. $80 \mathrm{~cm}^{3} 20 \%$ tincal mineral solution was mixed with $3 \mathrm{~cm}^{3}$ of $0.1 \%$ SP $100 \mathrm{~A}$ anionic flocculant at $80^{\circ} \mathrm{C}$. $70 \mathrm{~cm}^{3}$ of the clear solution on top of the settled particles were transferred to another beaker and the crystals obtained by cooling were separated by filtration. They were dried at $20^{\circ} \mathrm{C}$ and used in zinc borate synthesis. The flocculated particles were characterized as dolomite by Akdeniz et al. [29].

\subsection{Chemical Garden Preparation and Characteri- zation}

Zinc sulfate heptahydrate crystals were immersed in saturated borax decahydrate solution at $20^{\circ} \mathrm{C}$ for the formation of zinc borate chemical garden. Since it was not possible to record the photographs of the very small diameter transparent fibers by conventional photography, the same process was repeated using an optical microscope. A small crystal of zinc sulfate heptahydrate was placed on a drop of saturated borax solution at $20^{\circ} \mathrm{C}$ having $4.71 \%$ borax on a microscope slide and its photographs were captured in transmission mode by a digital camera fitted to Olympus, $\mathrm{CH} 40$ optical microscope at different time intervals.

\subsection{Preparation of Zinc Borate}

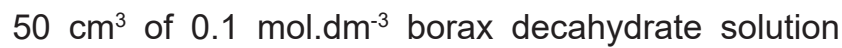
was mixed with $50 \mathrm{~cm}^{3} 0.1 \mathrm{~mol} \mathrm{dm}^{-3}$ with zinc sulfate heptahydrate at $90^{\circ} \mathrm{C}$ in a thermostatic shaking water bath up to 120 minutes. Samples withdrawn at different periods were filtered and the obtained precipitates were washed with water and dried at $105^{\circ} \mathrm{C}$ till constant mass was obtained.

\subsection{Characterization Methods}

FTIR of the samples were obtained with $\mathrm{KBr}$ disc method in $400-4000 \mathrm{~cm}^{-1}$ wavenumber range by using Shimadzu 8601 PC FTIR spectrophotometer. Setaram LABSYS TGA/DTA was used for thermal gravimetric analysis of the samples. The samples were heated from room temperature to $1000^{\circ} \mathrm{C}$ at $10^{\circ} \mathrm{C} \mathrm{min}{ }^{-1}$ rate under $40 \mathrm{~cm}^{3} \mathrm{~min}^{-1} \mathrm{~N}_{2}$ gas flow rate for this purpose. The powder X-ray diffraction (XRD) diagrams of the 
samples were obtained by using Philips Xpert-Pro Xray diffractometer. CuK radiation with $0.154 \mathrm{~nm}$ wavelength at $45 \mathrm{kV}$ and $40 \mathrm{~mA}$ was used and the data was recorded in $2 \theta$ range of $2-70^{\circ}$. Philips XL30 SFEG scanning electron microscope was used at accelerating voltage of 5 or $6 \mathrm{kV}$ to obtain the SEM micrographs of the samples coated with gold. EDX analyses of the pristine samples were made using the same instrument.

\section{Results and Discussion}

\subsection{Characterization of Purified Borax}

\subsubsection{X-ray diffraction diagram of borax}

X-ray diffraction diagram of borax sample used in the present study seen in Figure 1 had identical peaks with borax decahydrate (with JCPDS card number 0175-1078) [30]. The $2 \theta$ values of the peaks were the same but their relative intensities were different than reported in the reference [30] due to orientation of the crystals. The most intense peak is at $2 \theta$ value of $34^{\circ}$ indicated that crystals were oriented perpendicular to (024) plane [30].

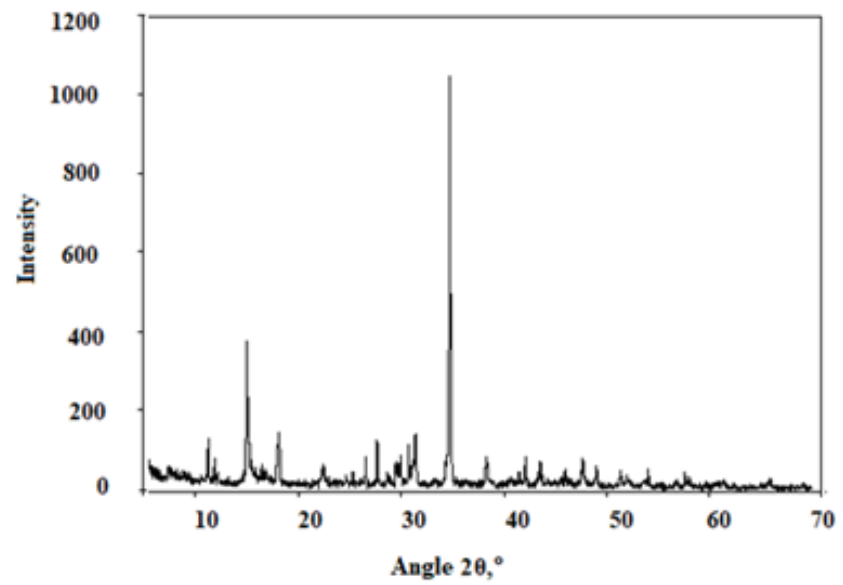

Figure 1. X-ray diffraction diagram of borax decahydrate.

\subsubsection{FTIR spectrum of borax}

The FTIR spectrum of borax from purified tincal mineral shown in Figure 2 confirms with the FTIR spectrum of borax decahydrate reported in literature [31,32].

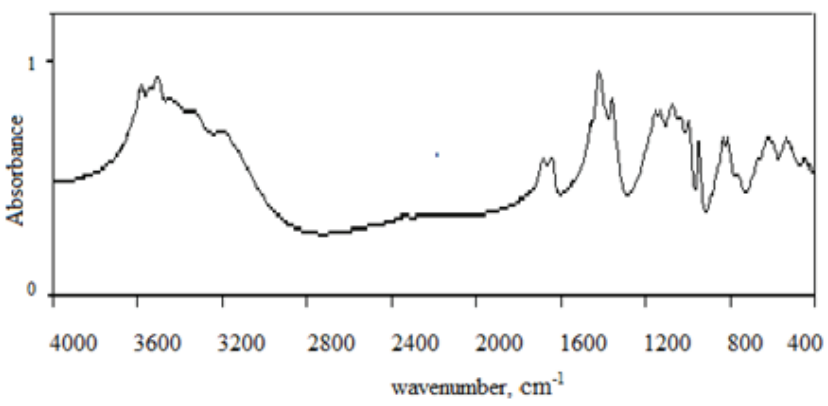

Figure 2. FTIR spectrum of borax decahydrate.

\subsubsection{Morphology of borax}

The SEM micrograph of borax decahydrate crystals seen in Figure 3 indicated they are in needle shape with length 5-10 $\mu \mathrm{m}$ and diameter 0.2-1 $\mu \mathrm{m}$. The X-ray diffraction diagram also indicated one dimensional orientation of borax decahydrate crystals. This could be due to templating effect of the flocculant (Superfloc100A) used for the removal of impurities in borax mineral by flocculation.

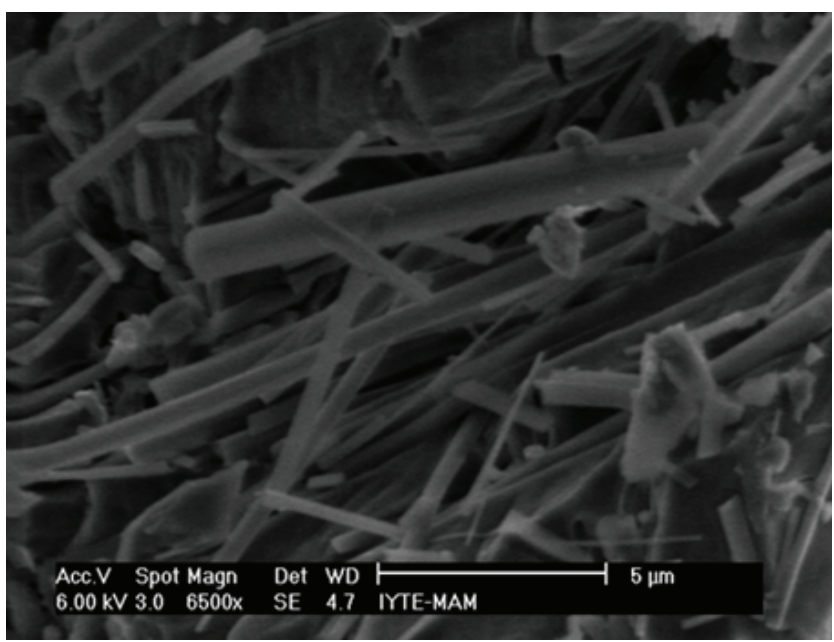

Figure 3. SEM micrograph of borax decahydrate.

\subsection{Chemical Garden}

Zinc sulfate heptahydrate particles were immersed in saturated borax solution at room temperature. Nearly transparent short chemical garden fibers formed in 30 minutes. Good photographs of the fibers could not be taken since they were transparent. Long fibers similar to the ones formed by immersion of zinc salts [5] and copper salts [11] to aqueous sodium silicate solution were not observed in the present case of aqueous borax zinc salt system. For this reason, it was attempted to monitor the fiber formation using an optical microscope. A small crystal of zinc sulfate heptahydrate was placed on top of a drop of saturated borax solution and the photographs were taken at different times. When zinc sulfate heptahydrate is placed in aqueous solution of borax solution it starts to dissolve to give $\mathrm{Zn}^{2+}$ and $\mathrm{SO}_{4}{ }^{2-}$ ions which react with the $\mathrm{OH}^{-}$and $\mathrm{B}_{4} \mathrm{O}_{7}{ }^{2-}$ ions in solution. A semipermeable membrane made out of possible solid reaction products such as $\mathrm{Zn}(\mathrm{OH})_{2}$, $\mathrm{Zn}_{4}(\mathrm{OH})_{6}\left(\mathrm{SO}_{4}\right)_{2} \cdot 4 \mathrm{H}_{2} \mathrm{O}$ and $2 \mathrm{ZnO} \cdot 3 \mathrm{~B}_{2} \mathrm{O}_{3} \cdot 3 \mathrm{H}_{2} \mathrm{O}$ covering the surface of sodium sulfate crystal is formed. Water can easily diffuse through the membrane creating a very high osmotic pressure in the crystal side. A saturated sodium sulfate solution forms on the surface of the crystals beneath the semipermeable membrane formed. Considering the solubility of sodium sulfate heptahydrate in water at $20^{\circ} \mathrm{C}\left(3.143 \mathrm{~mol} \mathrm{~kg}^{-1}\right)$ [33] the osmotic pressure created inside of the membrane is calculated as 22.95 MPa using Equation 6. 


$$
\pi=i c R T
$$

where $\pi$ is osmotic pressure, $i$ is number of ions formed by the dissociation of one mol substance, $c$ is concentration in $\mathrm{mol} \mathrm{m}^{-3}, R$ is the gas constant in $\mathrm{J}$ $\mathrm{mol}^{-1} \mathrm{~K}^{-1}$ and $T$ is temperature in $\mathrm{K}$. This high osmotic pressure first swells, then ruptures the membrane and saturated salt solution flows through the holes created on its surface into borax solution resulting formation of a new membrane with the reaction of borax and zinc sulfate. The membrane ruptures and reforms repeatedly. In crystal side of the membrane there is a concentrated zinc sulfate solution and at the other side of the membrane aqueous borax solution is present. The inside solution is ejected into outside solution at points ruptured on the membrane and thus a new membrane emanating from the center membrane is formed. Thus hollow fibers with $\mathrm{Zn}(\mathrm{OH})_{2}, \mathrm{Zn}_{4}(\mathrm{OH})_{6}\left(\mathrm{SO}_{4}\right)_{2} \cdot 4 \mathrm{H}_{2} \mathrm{O}$ and $2 \mathrm{ZnO} \cdot 3 \mathrm{~B}_{2} \mathrm{O}_{3} \cdot 3 \mathrm{H}_{2} \mathrm{O}$ would form. The micrographs of the process taken from optical microscope at different time periods are shown in Figure 4. The crystal immersed in solution is covered immediately with a membrane. At zero time the size of the membrane coated crystal is $100 \mu \mathrm{m}$ as observed in Figure $4 \mathrm{a}$ and $4 \mathrm{~b}$. The size expanded by swelling due to the inflow water through the membrane to $277 \mu \mathrm{m}$ in 302 seconds as seen in Figure 4c. The surface of the membrane is not smooth. The growth is not the same in all directions. Two branches in $108 \mu \mathrm{m}$ size emanated from a body of

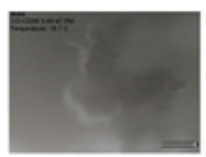

(a)

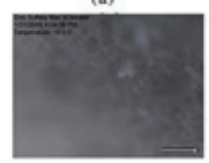

(e)

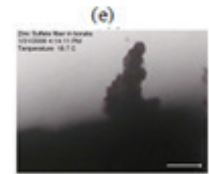

(i)

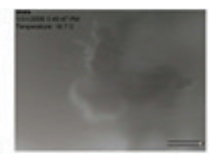

(b)

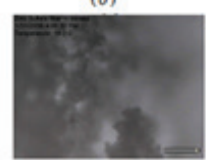

(f)

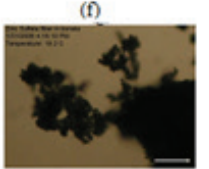

(i)

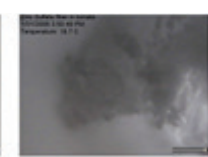

(c)

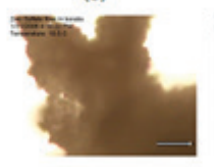

(2)

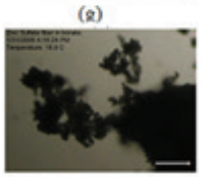

(k)

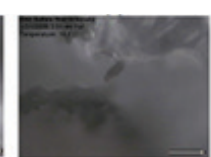

(d)

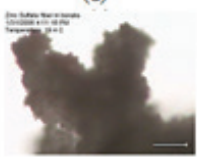

(h)
Figure 4. Optical micrographs of zinc sulfate hepta hydrate immersed in saturated borax solution at room temperature after immersion time of a and b. 0.0 , c. 302 , d. 357, e. 1129, f. 1245, g.1475, h.1529, i. 1704, j.1823, k. 1837 seconds (scale bar represents 100 $\mu \mathrm{m})$
$153 \mu \mathrm{m}$ in $1475 \mathrm{~s}$ in Figure 4g. A branch with $107 \mu \mathrm{m}$ at the bottom, $61 \mu \mathrm{m}$ in the middle and $15 \mu \mathrm{m}$ at the tip is seen in $1704 \mathrm{~s}$ in Figure 4i and particles having 31-138 $\mu \mathrm{m}$ with very tiny branches with $15 \mu \mathrm{m}$ diameter forms in $1837 \mathrm{~s}$ in Figure 4k. The optical microscope had shown the formation and expansion of branches of with irregular shapes. Filtering of the fibers formed by immersing zinc sulfate heptahydrate in borax solution, washing and drying would give hallow fibers having zinc borates, $\mathrm{Zn}(\mathrm{OH})_{2}, \mathrm{Zn}_{4}(\mathrm{OH})_{6}\left(\mathrm{SO}_{4}\right)_{2} \cdot 4 \mathrm{H}_{2} \mathrm{O}$.

\subsection{Characterization of Powders Obtained by Mi- xing Aqueous Tincal Mineral and Aqueous Zinc Heptahydrate Solutions}

\subsubsection{Elemental analysis of the powders}

EDX analysis gives information about the elemental composition of the surface of the powders. The elemental composition of the samples excluding hydrogen is shown in Table 1. In the same table molar ratios of $\mathrm{B}_{2} \mathrm{O}_{3} / \mathrm{ZnO}, \mathrm{Na} / \mathrm{S}$ and $\mathrm{Na} / \mathrm{Zn}$ are shown. Free water molecules in the surface of the powders would be separated since the system operates under vacuum. Thus the oxygen content of the surface would be lower due to water evaporation. The samples obtained by heating for different periods at $90^{\circ} \mathrm{C}$ during their preparation contained $\mathrm{B}, \mathrm{O}, \mathrm{Na}, \mathrm{S}$ and $\mathrm{Zn}$ elements as shown in Table 1. The molar ratio of $\mathrm{B}_{2} \mathrm{O}_{3} / \mathrm{ZnO}$ was close to 2. The presence of $\mathrm{S}$ and $\mathrm{Na}$ elements in the samples could be due to incomplete removal of the by product sodium sulfate or due to formation of double salts. However, there was higher amount of sodium element than that is equavalent to $\mathrm{S}$ element to form sodium sulfate. This indicated that sodium element was present in double salts formed during the reactions. Equation 7 represents formation of a double salt by the reactants in the mixture.

$$
\begin{aligned}
& \mathrm{Na}^{+}(\mathrm{aq})+\mathrm{B}_{4} \mathrm{O}_{7}{ }^{2-}(\mathrm{aq})+ \\
& 1 / 2 \mathrm{Zn}^{2+}(\mathrm{aq})+\mathrm{xH}_{2} \mathrm{O} \rightarrow \\
& \quad \mathrm{Na} \mathrm{Zn}_{1 / 2} \mathrm{~B}_{4} \mathrm{O}_{7} \cdot \mathrm{xH}_{2} \mathrm{O}(\mathrm{s})
\end{aligned}
$$

\subsubsection{FTIR analysis of the powders}

The FTIR spectra of the powders are shown in Figu-

\begin{tabular}{|c|c|c|c|c|c|c|c|c|}
\hline $\begin{array}{l}\text { Time, } \\
\text { minutes }\end{array}$ & $\begin{array}{c}\mathrm{B}, \text { mass } \\
(\%)\end{array}$ & $\begin{array}{c}\text { O, mass } \\
(\%)\end{array}$ & $\begin{array}{c}\text { Na, mass } \\
(\%)\end{array}$ & $\begin{array}{c}\mathrm{S}, \underset{(\%)}{\text { mass }} \\
\end{array}$ & $\begin{array}{c}\mathrm{Zn} \text {, mass } \\
(\%)\end{array}$ & $\begin{array}{c}\mathrm{B}_{2} \mathrm{O}_{3} / \mathrm{ZnO} \\
\text { Mol ratio }\end{array}$ & $\begin{array}{c}\mathrm{Na} / \mathrm{S} \\
\text { Mol ratio }\end{array}$ & $\mathrm{Na} / \mathrm{Zn}$ \\
\hline 0 & 14.49 & 37.91 & 20.35 & 3.32 & 23.93 & 1.83 & 8.52 & 2.41 \\
\hline 30 & 17.70 & 34.88 & 15.27 & 0.94 & 31.22 & 1.71 & 22.60 & 1.39 \\
\hline 60 & 19.30 & 41.55 & 16.47 & 1.07 & 21.61 & 2.70 & 21.41 & 2.16 \\
\hline 90 & 15.58 & 39.91 & 19.53 & 0.90 & 24.09 & 1.95 & 30.19 & 2.30 \\
\hline 120 & 15.58 & 40.00 & 19.53 & 1.16 & 25.79 & 1.98 & 23.42 & 2.34 \\
\hline
\end{tabular}
re 5. The presence of the absorption maxima at 3400 $\mathrm{cm}^{-1}$ for hydrogen bonded $\mathrm{OH}$ and at $1640 \mathrm{~cm}^{-1}$ for $\mathrm{H}_{2} \mathrm{O}$

Table 1. The elemental composition of the samples heated for different time periods at $90^{\circ} \mathrm{C}$ during their preparation. 
bending vibrations indicated presence of $\mathrm{OH}$ groups and $\mathrm{H}_{2} \mathrm{O}$ in the samples. In the spectra of all samples the vibrations of O-B-O in planar $\left(\mathrm{B}_{(3)}-\mathrm{O}\right)$ and vibrations of O-B-O in tetrahedral $\left(\mathrm{B}_{(4)}-\mathrm{O}\right)$ geometries and vibrations of $\mathrm{B}-\mathrm{O}-\mathrm{H}$ are seen [19]. The ratio of absorbance of $\mathrm{B}_{(3)}-\mathrm{O}$ vibrations at $1351 \mathrm{~cm}^{-1}$ to absorbance of $\mathrm{B}_{(4)}-\mathrm{O}$ vibrations at $1026 \mathrm{~cm}^{-1}$ increased with heating period at $90^{\circ} \mathrm{C}$ during preparation of the powder samples as shown in Table 2. This indicated the formation of planar borate ions with the expense of tetrahedral borate ions with time. Bending vibrations of $\mathrm{B}-\mathrm{O}-\mathrm{H}$ that should be observed in 1221 and $1108 \mathrm{~cm}^{-1}$ range overlapped with tetrahedral O-B-O vibrations. The bending vibration of planar O-B-O in $\left(\mathrm{B}_{(3)}-\mathrm{O}\right)$ is observed at 660 $\mathrm{cm}^{-1}$ [19].

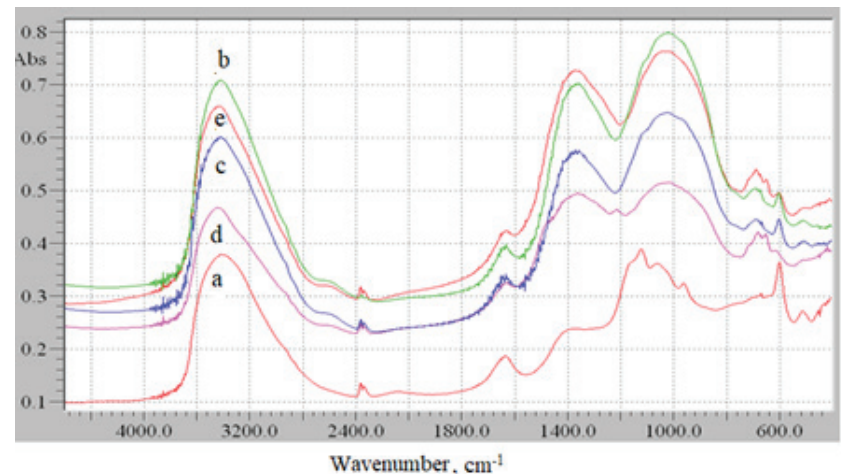

Figure 5. FTIR spectrum of the samples heated at $90^{\circ} \mathrm{C}$ during preparation for heating times of a) 0 , b) 30 , c) 60 , d) 90 , e) 120 minutes.

Table 2. The ratio of absorbance of $\mathrm{B}_{(3)}-\mathrm{O}$ asymmetric stretching vibrations at $1351 \mathrm{~cm}^{-1}$ to $\mathrm{B}_{(4)}-\mathrm{O}$ asymmetric stretching vibrations at $1026 \mathrm{~cm}^{-1}$ for samples heated for different time periods at $90^{\circ} \mathrm{C}$ during their preparation.

\begin{tabular}{cc}
\hline $\begin{array}{c}\text { Time } \\
\text { (minutes) }\end{array}$ & $\begin{array}{c}\text { Intensity of } 1351 \mathbf{c m}^{-1} \text { I } \\
\text { Intensity of } 1026 \mathbf{c m}^{-1}\end{array}$ \\
\hline 0 & 0.67 \\
30 & 0.88 \\
60 & 0.88 \\
90 & 0.98 \\
120 & 0.99 \\
\hline
\end{tabular}

The presence of the bands for $\mathrm{Zn}(\mathrm{OH})_{2}$ at $1086 \mathrm{~cm}^{-1}$ and $1029 \mathrm{~cm}^{-1}$ due to asymmetric stretching vibrations of $\mathrm{Zn}-\mathrm{O}-\mathrm{Zn}$ and at $717 \mathrm{~cm}^{-1}$ due to bending vibrations of $\mathrm{OH}$ groups in $\mathrm{Zn}(\mathrm{OH})_{2}$ indi-cated that the $\mathrm{Zn}(\mathrm{OH})_{2}$ was also present in the powders [34]. The small sharp band observed at $600 \mathrm{~cm}^{-1}$ in Figure 5 could be attributed to the bending vibrations of sulfate ion that must be observed at $617 \mathrm{~cm}^{-1}$ [35]. The antisymmetric stretching vibrations of sulfate groups that should be observed at $1106 \mathrm{~cm}^{-1}$ [35] overlaps with the broad band observed for antisymmetric stretc-hing vibrations of $\mathrm{O}-\mathrm{B}-\mathrm{O}$ in $\mathrm{B}_{(4)}-\mathrm{O}$.
FTIR spectroscopy indicated presence of planar and tetrahedral borate groups, $\mathrm{Zn}(\mathrm{OH})_{2}$ and sulfate groups. The FTIR spectrum of the powder formed at the first instant of mixing two reactant solutions indicated higher sulfate content than the powders obtained by further heating.

\subsubsection{X-ray diffraction}

X-ray diffraction diagram of the samples obtained for different heating periods are depicted in Figure 6. Sharp peaks at $2 \theta$ values of $9.4^{\circ}, 18.8^{\circ}, 21.6^{\circ}, 25.9^{\circ}$, $27.4^{\circ}, 29.5^{\circ}, 32.9^{\circ}, 34.8^{\circ}$, and $59.8^{\circ}$ were observed in the X-ray diffraction diagram (curve e in Figure 6) of the sample heated for 120 minutes in its preparation. The peaks for sodium sulfate by product were also investigated since the EDX analysis indicated the presence of sulfur element. The peaks expected at $22.5^{\circ}$, $23.6^{\circ}, 25.5^{\circ}, 37.9^{\circ}, 46.3^{\circ}, 48.9^{\circ}$ for sodium sulfate (JCPDS card number 36-0397) [36] were not present in Figure 6. Thus sodium sulfate was present as only in small amount as impurity. The presence of peaks at $2 \theta$ values of $31.7^{\circ}, 34.3^{\circ}, 36.2^{\circ}$ (JCPDS card number 79-0206) would indicate the presence of $\mathrm{ZnO}$ in the samples [37]. ZnO also was not present since these peaks were absent. $\mathrm{Zn}(\mathrm{OH})_{2}$ crystals have peaks at $2 \theta$ values of $15.4^{\circ}, 15.8^{\circ}, 26.0^{\circ}, 27.0^{\circ}, 27.8^{\circ}, 29.6^{\circ}$, $30.9^{\circ}, 31.8^{\circ}, 34.2^{\circ}, 36.0^{\circ}, 36.3^{\circ}, 37.0^{\circ}, 38.4^{\circ}, 39.1^{\circ}$, $42^{\circ}, 47.1^{\circ}, 48.5^{\circ}$ and $49.3^{\circ}$ in its XRD pattern. [34]. $\beta-\mathrm{Zn}(\mathrm{OH})_{2}$ was present in the samples since most of these peaks were present in the x-ray diffraction diagram in Figure 6.

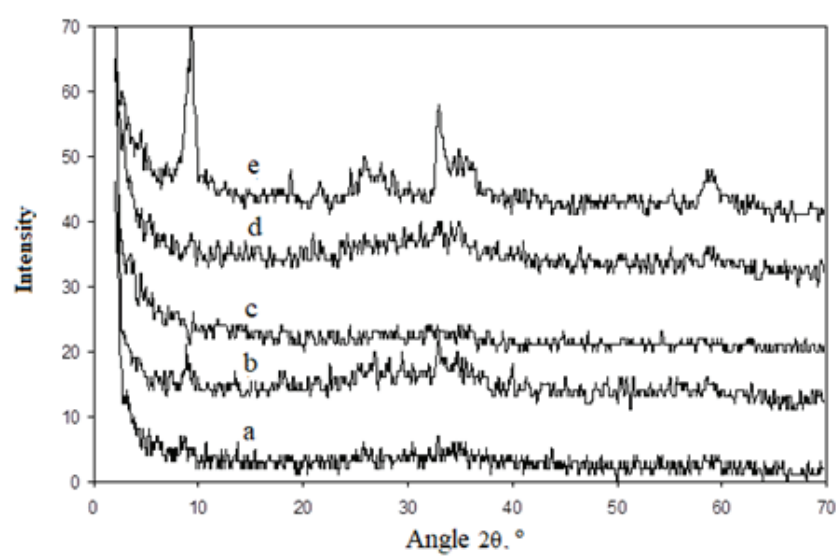

Figure 6. X-ray diffraction diagrams of the samples heated at $90^{\circ} \mathrm{C}$ during preparation for heating times of a) 0 , b) 30 , c) 60 , d) 90 , e) 120 minutes.

Formation of $\mathrm{Zn}_{4}(\mathrm{OH})_{6}\left(\mathrm{SO}_{4}\right) \cdot 4 \mathrm{H}_{2} \mathrm{O}$ [38] is another possibility in the system according to Equation 8.

$$
\begin{aligned}
& 4 \mathrm{Zn}^{2+}{ }_{(\mathrm{aq})}+6 \mathrm{OH}^{-}(\mathrm{aq})+\mathrm{SO}_{4}{ }^{2-}+4 \mathrm{H}_{2} \mathrm{O}_{(\mathrm{l})}-\rightarrow \\
& \mathrm{Zn}_{4}(\mathrm{OH})_{6}\left(\mathrm{SO}_{4}\right) \cdot 4 \mathrm{H}_{2} \mathrm{O}_{(\mathrm{s})}
\end{aligned}
$$

The observed X-ray diffraction peaks of the samples partially coincides with X-ray diffraction peaks of 
$\mathrm{Zn}_{4}(\mathrm{OH})_{6}\left(\mathrm{SO}_{4}\right) \cdot 4 \mathrm{H}_{2} \mathrm{O}$ with ASTM Powder file 9-204 [39]. Also $2 \mathrm{ZnO} \cdot 3 \mathrm{~B}_{2} \mathrm{O}_{3} \cdot 3 \mathrm{H}_{2} \mathrm{O}$ and $2 \mathrm{ZnO} \cdot 3 \mathrm{~B}_{2} \mathrm{O}_{3} \cdot 7 \mathrm{H}_{2} \mathrm{O}$ peaks [40] were not present. X-ray diffraction diagrams of the samples indicated the presence of $\mathrm{Zn}(\mathrm{OH})_{2}$ and $\mathrm{Zn}_{4}(\mathrm{OH})_{6}\left(\mathrm{SO}_{4}\right) \cdot 4 \mathrm{H}_{2} \mathrm{O}$ crystals in the samples. Even if $2 \mathrm{ZnO} \cdot 3 \mathrm{~B}_{2} \mathrm{O}_{3} \cdot 3 \mathrm{H}_{2} \mathrm{O}$ and $2 \mathrm{ZnO} \cdot 3 \mathrm{~B}_{2} \mathrm{O}_{3} \cdot 7 \mathrm{H}_{2} \mathrm{O}$ were present in the samples they were not in crystalline form or they had very small crystals that caused line broadening and overlapping.

\subsubsection{Thermal analysis of the samples}

The TG curves of the samples in Figure 7 showed two steps of mass decrease as tabulated in Table 3. The first step in $150-350^{\circ} \mathrm{C}$ range is most probably due to elimination of $\mathrm{H}_{2} \mathrm{O}$ from $\mathrm{Zn}(\mathrm{OH})_{2}$ and $\mathrm{Zn}_{4}(\mathrm{OH})_{6}\left(\mathrm{SO}_{4}\right) \cdot 4 \mathrm{H}_{2} \mathrm{O}$ and possible zinc borate hydrates. The second step in $700-950^{\circ} \mathrm{C}$ range could be due to decomposition of sulfate ions as shown below [38].

$$
\mathrm{SO}_{4}{ }^{2-} \rightarrow \mathrm{SO}_{2}(\mathrm{~g})+\mathrm{O}_{2}(\mathrm{~g})+2 \mathrm{e}^{-}
$$

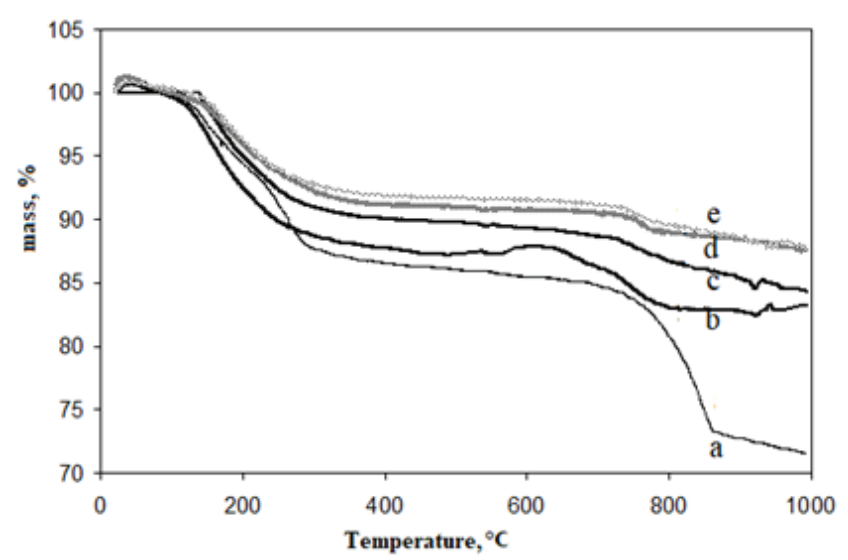

Figure 7. TG curves of crystals obtained after heating at $90^{\circ} \mathrm{C}$ during preparation for heating times of a) 0, b) 30, c) 60, d) 90, e) 120 minutes.

TG analysis showed that the compounds with high water and sulfate content forms at the first instant of the reaction and the water content and sulfate content decrease as the heating period at $90^{\circ} \mathrm{C}$ increases. The change in the water content of the compounds is smal- ler than the decrease in sulfate content with heating period. While the water content decreases from $12 \%$ to $9 \%$, the sulfate content decreases from 10 to $1 \%$.

\subsubsection{Morphology of the samples}

The SEM micrograph of the sample heated for $30 \mathrm{mi}-$ nutes at $90^{\circ} \mathrm{C}$ in Figure 8 showed that it consists of agglomerated primary particles of $600 \mathrm{~nm}$ average diameter. The primary particles should have adhered to each other during drying process.

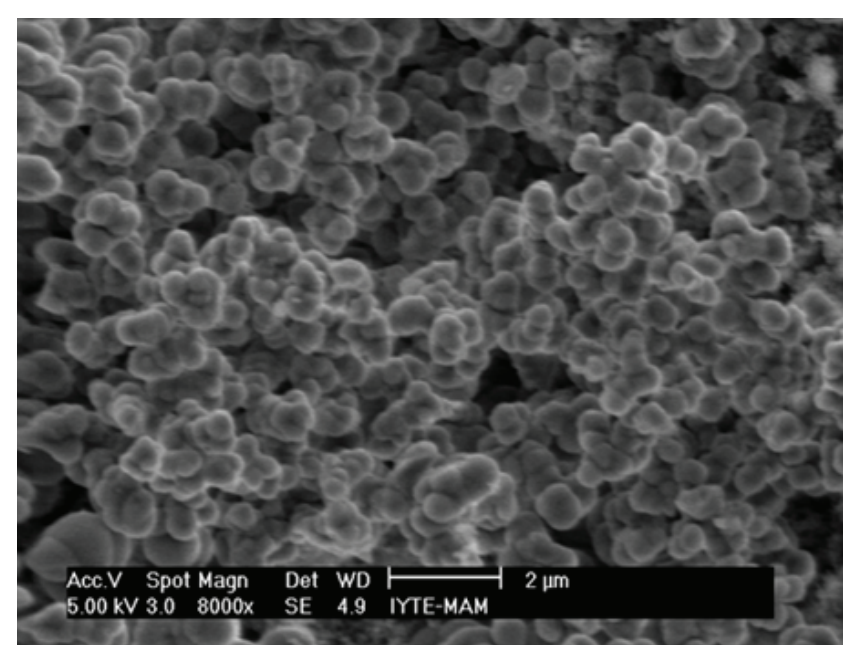

Figure 8. SEM micrograph of the sample heated for 30 minutes at $90^{\circ} \mathrm{C}$ during its preparation.

\subsection{Discussion}

Producing zinc borates either in hallow fiber form or powder form from tincal mineral and zinc sulfate heptahydrate was investigated in this work. Since in the aqueous reaction medium $\mathrm{OH}^{-}, \mathrm{Na}^{+}, \mathrm{SO}_{4}{ }^{2-}$ were also present besides $\mathrm{B}_{4} \mathrm{O}_{7}^{-2}$ and $\mathrm{Zn}^{2+}$ ions the formed powders were not pure zinc borates but they also contained $\mathrm{Zn}(\mathrm{OH})_{2}, \mathrm{Zn}_{4}(\mathrm{OH})_{6}\left(\mathrm{SO}_{4}\right) \cdot 4 \mathrm{H}_{2} \mathrm{O}$ and $\mathrm{Na} \mathrm{Zn}_{1 / 2} \mathrm{~B}_{4} \mathrm{O}_{7}$. $\mathrm{xH}_{2} \mathrm{O}$. The x-ray diffraction diagrams showed the presence of crystalline $\mathrm{Zn}(\mathrm{OH})_{2}$ and $\mathrm{Zn}_{4}(\mathrm{OH})_{6}\left(\mathrm{SO}_{4}\right) \cdot 4 \mathrm{H}_{2} \mathrm{O}$ phases and FTIR spectroscopy and EDX analysis indicated presence of hydrated zinc borates and $\mathrm{Na} \mathrm{Zn}_{1 / 2}$ $\mathrm{B}_{4} \mathrm{O}_{7} \cdot \mathrm{xH}_{2} \mathrm{O}$. Using dilute borax decahydrate and dilute

Table 3. The temperature range and the mass $\%$ range for the step 1 and step 2 in TG curves in Figure 7 for the samples heated for different periods at $90^{\circ} \mathrm{C}$ during their preparation.

\begin{tabular}{ccccccc}
\hline $\begin{array}{c}\text { Heating } \\
\text { time } \\
\text { minutes }\end{array}$ & $\begin{array}{c}\text { Temperature } \\
\text { range }\left({ }^{\circ} \mathbf{C}\right)\end{array}$ & $\begin{array}{c}\text { Mass Range } \\
(\%)\end{array}$ & $\begin{array}{c}\text { Mass } \\
\text { Loss (\%) }\end{array}$ & $\begin{array}{c}\text { Temperature } \\
\text { Range }\left({ }^{\circ} \mathbf{C}\right)\end{array}$ & $\begin{array}{c}\text { Mass } \\
\text { range (\%) }\end{array}$ & $\begin{array}{c}\text { Mass } \\
\text { Loss (\%) }\end{array}$ \\
\hline $\mathbf{0}$ & $150-300$ & $100-88$ & 12 & $700-850$ & $84-74$ & 10 \\
$\mathbf{3 0}$ & $150-260$ & $100-91$ & 9 & $650-760$ & $88-84$ & 4 \\
$\mathbf{6 0}$ & $150-350$ & $100-93$ & 7 & $730-940$ & $88-85$ & 3 \\
$\mathbf{9 0}$ & $150-350$ & $100-92$ & 8 & $730-760$ & $91-90$ & 1 \\
$\mathbf{1 2 0}$ & $150-350$ & $100-91$ & 9 & $730-760$ & $92-91$ & 1 \\
\hline
\end{tabular}


zinc sulfate heptahydrate solutions $\left(0.1 \mathrm{~mol} \mathrm{dm}^{-3}\right)$ in the present study resulted in formation of submicron particles since there were not enough borate, zinc and $\mathrm{OH}^{-}$ions for the growth of the nucleated zinc borate, $\mathrm{Zn}(\mathrm{OH})_{2}$ and $\mathrm{Zn}_{4}(\mathrm{OH})_{6}\left(\mathrm{SO}_{4}\right) \cdot 4 \mathrm{H}_{2} \mathrm{O}$ particles. In studies made with higher of borax concentrations resulted well defined micron sized crystals of $Z_{3} \mathrm{~B}_{6} \mathrm{O}_{12} \cdot 3.5 \mathrm{H}_{2} \mathrm{O}$ $[24,40]$ or $\mathrm{Zn}_{2} \mathrm{~B}_{6} \mathrm{O}_{11} \cdot 7 \mathrm{H}_{2} \mathrm{O}$ [27]. When boric acid was added to the mixture of aqueous sodium sulfate and borate with excess zinc ions resulted in well-defined crystals of $\mathrm{Zn}_{3} \mathrm{~B}_{6} \mathrm{O}_{12} \cdot 3.5 \mathrm{H}_{2} \mathrm{O}$ were obtained by sonochemical method [40]. Even if the submicron particles obtained in the present study was not pure zinc borate, they can be easily dispersed in mineral oil to increase the lubrication efficiency of the mineral oil for reduction of wear of metal parts as in the study of Savrik et al [26].

\section{Conclusions}

The formation of chemical garden from zinc sulfate heptahydrate crystals immersed in saturated borax solution was monitored with optical microscope. The formation of the first membrane, the swelling of the crystal by incoming water from the semipermeable membrane and the formation of branches with irregular shapes were observed by optical microscopy. Thus it would be possible to obtain hallow zinc borate fibers by immersing zinc sulfate heptahydrate in saturated borax solution.

The solid reaction products obtained by mixing dilute aqueous borax and zinc sulfate solutions were attempted to be characterized in the present study. Elemental analysis indicated the presence of $\mathrm{B}, \mathrm{O}, \mathrm{Na}, \mathrm{S}$ and $\mathrm{Zn}$ elements. The $\mathrm{B}_{2} \mathrm{O}_{3} / \mathrm{ZnO}$ ratio was changing around 2 . Double salt formation was also possible as indicated by the high $\mathrm{Na}$ content of the powders. FTIR analysis showed that the ratio of absorbance of asymmetric stretching vibrations of $\left(\mathrm{B}_{(3)}-\mathrm{O}\right)$ at $1351 \mathrm{~cm}^{-1}$ to absorbance of asymmetric stretching vibrations of $\left(\mathrm{B}_{(4)}-\mathrm{O}\right)$ at $1026 \mathrm{~cm}^{-1}$ increased during heating of the powder during its preparation indicating tetrahedral borate ions were transformed to trihedral borate ions. Presence of $\mathrm{Zn}(\mathrm{OH})_{2}$ and $\mathrm{SO}_{4}{ }^{2-}$ ions in the first precipitate formed was indicated by FTIR analysis. The samples contained $\mathrm{Zn}_{4}(\mathrm{OH})_{6}\left(\mathrm{SO}_{4}\right) \cdot 4 \mathrm{H}_{2} \mathrm{O}$ as indicated by $T \mathrm{G}$ analysis. X-ray diffraction confirmed the presence of $\mathrm{Zn}(\mathrm{OH})_{2}$ and additionally presence of $\mathrm{Zn}_{4}(\mathrm{OH})_{6}\left(\mathrm{SO}_{4}\right) \cdot 4 \mathrm{H}_{2} \mathrm{O}$. The zinc borate compounds formed were not crystalline or had very small crystals since no sharp $\mathrm{x}$-ray diffraction peaks of zinc borate species were observed. The two mass loss steps at $150-350^{\circ} \mathrm{C}$ and $700-950^{\circ} \mathrm{C}$ ranges were due to elimination of water and the decomposition of sulfate ions respectively. The precipitate formed initially had $10 \%$ sulfate and the sulfate content decreased to $1 \%$ for the sample produced in 90 minutes heating time at $90^{\circ} \mathrm{C}$. The precipitated powder from tincal mineral and zinc heptahydrate solution was not pure. Its composition was changing with heating time during its preparation and it contained $\mathrm{Zn}(\mathrm{OH})_{2}$, $\mathrm{Zn}_{4}(\mathrm{OH})_{6}\left(\mathrm{SO}_{4}\right) \cdot 4 \mathrm{H}_{2} \mathrm{O}, \mathrm{Na} \mathrm{Zn} \mathrm{n}_{1 / 2} \mathrm{~B}_{4} \mathrm{O}_{7} \cdot \mathrm{xH}_{2} \mathrm{O}$ besides zinc borates. The powder could be used as a lubricant additive, since it could be easily dispersed in mineral oil due to $600 \mathrm{~nm}$ diameter primary particles.

\section{Acknowledgements}

The authors thank to Turkish Scientific and Technological Research Council for supporting this study with project number $105 \mathrm{M} 358$.

\section{References}

[1] Barge, L. M., Cardoso, S. S., Cartwright, J. H., Cooper, G. J., Cronin, L., De Wit, A., ... \& Thomas, N. L. (2015). From chemical gardens to chemobrionics. Chemical Reviews, 115(16), 8652-8703.

[2] Cartwright, J. H., Escribano, B., \& Sainz-Díaz, C. I. (2011). Chemical-garden formation, morphology, and composition. I. Effect of the nature of the cations. Langmuir, 27(7), 3286-3293.

[3] Cartwright, J. H., Escribano, B., Khokhlov, S., \& SainzDíaz, C. I. (2011). Chemical gardens from silicates and cations of group 2: a comparative study of composition, morphology and microstructure. Physical Chemistry Chemical Physics, 13(3), 1030-1036.

[4] Glaab, F., Kellermeier, M., Kunz, W., Morallon, E., \& García-Ruiz, J. M. (2012). Formation and evolution of chemical gradients and potential differences across self-assembling inorganic membranes. Angewandte Chemie, 124(18), 4393-4397.

[5] Balköse, D., Özkan, F., Köktürk, U., Ulutan, S., Ülkü, S., \& Nişli, G. (2002). Characterization of hollow chemical garden fibers from metal salts and water glass. Journal of Sol-Gel Science and Technology, 23(3), 253-263.

[6] Parmar, K., \& Bhattacharjee, S. (2017). Energetically benign synthesis of lanthanum silicate through "silica garden" route and its characterization. Materials Chemistry and Physics, 194, 147-152.

[7] Makki, R., Al-Humiari, M., Dutta, S., \& Steinbock, O. (2009). Hollow microtubes and shells from reactantloaded polymer beads. Angewandte Chemie, 121(46), 8908-8912.

[8] Glaab, F., Rieder, J., Klein, R., Choquesillo-Lazarte, D., Melero-Garcia, E., García-Ruiz, J. M., ... \& Kellermeier, M. (2017). Precipitation and crystallization kinetics in silica gardens. ChemPhysChem, 18(4), 338345.

[9] Bormashenko, E., Bormashenko, Y., Grynyov, R., Pogreb, R., \& Schechter, A. (2015). How to grow a movable mini-garden in a droplet: Growing chemical gardens in a water and aqueous ethanol solutions droplets deposited on a superhydrophobic surface. Colloids and Interface Science Communications, 7, 12-15.

[10] Bormashenko, E., Bormashenko, Y., Stanevsky, O., 
Pogreb, R., Whyman, G., Stein, T., \& Barkay, Z. (2006). Template-assisted growth of chemical gardens: Formation of dendrite structures. Colloids and Surfaces A: Physicochemical and Engineering Aspects, 289(1-3), 245-249.

[11] Escamilla-Roa, E., Cartwright, J. H., \& Sainz-Díaz, C. I. (2019). Chemobrionic fabrication of hierarchical self-assembling nanostructures of copper oxide and hydroxide. ChemSystemsChem, 1(3), e1900011.

[12] Zhao, W., \& Sakurai, K. (2017). Realtime observation of diffusing elements in a chemical garden. ACS Omega, 2(8), 4363-4369.

[13] Schubert, D. M. (2019). Hydrated zinc borates and their industrial use. Molecules, 24(13), 2419.

[14] Eltepe, H. E., Balköse, D., \& Ülkü, S. (2007). Effect of temperature and time on zinc borate species formed from zinc oxide and boric acid in aqueous medium. Industrial \& Engineering Chemistry Research, 46(8), 2367-2371.

[15] Gao, P., \& Zhang, Y. (2015). Synthesis and characterization of zinc borate nanowhiskers and their inflaming retarding effect in polystyrene. Journal of Nanomaterials, 2015.

[16] Gao, Y. H., \& Liu, Z. H. (2009). Hydrothermal synthesis and standard molar enthalpy of formation of zinc borate of $4 \mathrm{ZnO} \cdot \mathrm{B} 2 \mathrm{O} 3 \cdot \mathrm{H} 2 \mathrm{O}$. Journal of Chemical \& Engineering Data, 54(9), 2789-2790.

[17] Gao, Y. H., \& Liu, Z. H. (2009). Synthesis and thermochemistry of two zinc borates, Zn2B6O11.7H2O and Zn3B10O18-14H2O. Thermochimica Acta, 484(1-2), 27-31.

[18] Kipcak, A. S., Senberber, F. T., Derun, E. M., Tugrul, N., \& Piskin, S. (2015). Characterization and thermal dehydration kinetics of zinc borates synthesized from zinc sulfate and zinc chloride. Research on Chemical Intermediates, 41(11), 9129-9143.

[19] Kipcak, A. S., Senberber, F. T., Yildirim, M., Yuksel, S. A., Derun, E. M., \& Tugrul, N. (2016). Characterization and physical properties of hydrated zinc borates synthesized from sodium borates. Main Group Metal Chemistry, 39(1-2), 59-66.

[20] Kipcak, A. S., Acarali, N., Senberber, F. T., Yildirim, M., Koc, S. N. T., Yuksel, S. A., ... \& Tugrul, N. (2016). Synthesis of dehydrated zinc borates using the solidstate method: Characterization and investigation of the physical properties. Main Group Chemistry, 15(4), 301-313.

[21] Shi, X., Li, M., Yang, H., Chen, S., Yuan, L., Zhang, K., \& Sun, J. (2007). PEG-300 assisted hydrothermal synthesis of $4 \mathrm{ZnO} \cdot \mathrm{B} 2 \mathrm{O} 3 \cdot \mathrm{H} 2 \mathrm{O}$ nanorods. Materials Research Bulletin, 42(9), 1649-1656.

[22] Liang, P., Tuoheti, Z., \& Liu, Z. H. (2017). Controlling the structure and morphology of zinc borate by adjusting the reaction temperature and $\mathrm{pH}$ value: formation mechanisms and luminescent properties. RSC $\mathrm{Ad}$ vances, 7(7), 3695-3703

[23] Nies, N. P., \& Hulbert, R. W. (1970). U.S. Patent No.
3,549,316. Washington, DC: U.S. Patent and Trademark Office.

[24] Shi, X., Xiao, Y., Yuan, L., \& Sun, J. (2009). Hydrothermal synthesis and characterizations of $2 \mathrm{D}$ and $3 \mathrm{D}$ $4 \mathrm{ZnO} \cdot \mathrm{B} 2 \mathrm{O} 3 \cdot \mathrm{H} 2 \mathrm{O}$ nano/microstructures with different morphologies. Powder Technology, 189(3), 462-465.

[25] Tian, Y., Guo, Y., Jiang, M., Sheng, Y., Hari, B., Zhang, G., ... \& Wang, Z. (2006). Synthesis of hydrophobic zinc borate nanodiscs for lubrication. Materials Letters, 60(20), 2511-2515.

[26] Savrık, S. A., Alp, B., Üstün, F., \& Balköse, D. Nano Zinc Borate as a Lubricant Additive. Journal of the Turkish Chemical Society Section A: Chemistry, 5(1), 45-52.

[27] Zheng, Y., Tian, Y., Ma, H., Qu, Y., Wang, Z., An, D., ... \& Gao, X. (2009). Synthesis and performance study of zinc borate nanowhiskers. Colloids and Surfaces $A$ : Physicochemical and Engineering Aspects, 339(1-3), 178-184.

[28] Polat, S., \& Sayan, P. Box-Behnken experimental design for zinc borate $\mathrm{Zn} 2 \mathrm{~B} 6 \mathrm{O} 11 \cdot 7 \mathrm{H} 2 \mathrm{O}$. Journal of Boron, 5(3), 152-161.

[29] Akdeniz, Y., Özmihci, F., Duvarcı, O. Ç., Balköse, D., Ülkü, S. (2003, September 3-6). Kırka tinkal mineralinin sulu çözeltilerindeki kolloidal fazın karakterizasyonu [Characterization of colloidal phase of Kırka tinkal mineral solution in water]. In 11th Symposium of Clay, İzmir, Turkey.

[30] Goel, N., Sinha, N., \& Kumar, B. (2013). Growth and properties of sodium tetraborate decahydrate single crystals. Materials Research Bulletin, 48(4), 16321636.

[31] Jun, L., Shuping, X., \& Shiyang, G. (1995). FT-IR and Raman spectroscopic study of hydrated borates. Spectrochimica Acta Part A: Molecular and Biomolecular Spectroscopy, 51(4), 519-532.

[32] Polat, S., \& Sayan, P. Effects of polyelectrolytes on the hardness of borax decahydrate crystals. Journal of Boron, 4(4), 172-179.

[33] Steiger, M., \& Asmussen, S. (2008). Crystallization of sodium sulfate phases in porous materials: the phase diagram Na2SO4- $\mathrm{H} 2 \mathrm{O}$ and the generation of stress. Geochimica et Cosmochimica Acta, 72(17), 42914306.

[34] Top, A., \& Çetinkaya, H. (2015). Zinc oxide and zinc hydroxide formation via aqueous precipitation: Effect of the preparation route and lysozyme addition. Materials Chemistry and Physics, 167, 77-87.

[35] Zhou, J., Santambrogio, G., Brümmer, M., Moore, D. T., Wöste, L., Meijer, G., ... \& Asmis, K. R. (2006). Infrared spectroscopy of hydrated sulfate dianions. Journal of Chemical Physics, 125(11), 111102-111102.

[36] Linnow, K., Zeunert, A., \& Steiger, M. (2006). Investigation of sodium sulfate phase transitions in a porous material using humidity-and temperature-controlled X-ray diffraction. Analytical Chemistry, 78(13), 46834689. 
[37] Egbuchunam, T., \& Balkose, D. (2012). Effect of supercritical ethanol drying on the properties of zinc oxide nanoparticles. Drying Technology, 30(7), 739-749.

[38] Staminirova, T., Petrova, N., \& Kirov, G. (2016). Thermal decomposition of zinc hydroxy-sulfate-hydrate minerals. Journal of Thermal Analysis and Calorimetry, 125(1), 85-96.

[39] Bevins, R. E., Turgoose, S., \& Williams, P. A. (1982). Namuwite, $(\mathrm{Zn}, \mathrm{Cu}) 4 \mathrm{SO} 4(\mathrm{OH}) 6 \cdot 4 \mathrm{H} 2 \mathrm{O}$, a new mineral from Wales. Mineralogical Magazine, 46(338), 51-54.

[40] Ersan, A. C., Kipcak, A. S., Ozen, M. Y., \& Tugrul, N. (2020). An accelerated and effective synthesis of zinc borate from zinc sulfate using sonochemistry. Main Group Metal Chemistry, 43(1), 7-14. 